\title{
Arkadiusz Piwowar
}

Uniwersytet Ekonomiczny we Wrocławiu

e-mail: arkadiusz.piwowar@ue.wroc.pl

\section{JAKOŚĆ HANDLOWA WYBRANYCH GRUP TOWAROWYCH ARTYKULÓW ROLNO-SPOŻYWCZYCH W POLSCE}

\begin{abstract}
Streszczenie: W niniejszym artykule przedstawiono wybrane zagadnienia dotyczące jakości handlowej wybranych grup artykułów rolno-spożywczych w Polsce w latach 2010-2012. Jak wynika z analiz, w badanym okresie wzrosła liczba próbek o niewłaściwej jakości handlowej, m.in. w grupie towarowej: „pieczywo cukiernicze, ciasta i ciastka”, „wyroby cukiernicze”, „pieczywo”, „drób i jego przetwory” oraz „mięso i jego przetwory”. Porównanie wyników kontroli wykazało poprawę jakości handlowej napojów spirytusowych oraz piwa i surowców browarniczych. W artykule przedstawiono przykłady uchybień w przestrzeganiu przepisów dotyczących jakości handlowej wybranych grup artykułów rolno-spożywczych.
\end{abstract}

Słowa kluczowe: jakość handlowa, żywność, IJHARS.

DOI: $10.15611 /$ nit.2014.2.08

\section{Wstęp}

Termin ,jakość” należy do jednych z najczęściej używanych przez ludzi w różnych sytuacjach. Chociaż jest on ogólnie zrozumiały, jednoznaczne i precyzyjne określenie pojęcia ,jakość” jest problemem towarzyszącym człowiekowi od czasów starożytnych po teraźniejszość. Warto w tym miejscu podać definicję Platona: ,jakość jest to pewien stopień doskonałości" [Kiliński 1979] oraz Crosby'ego: ,jakość to zgodność z wymaganiami" [Łuczak 2007]. Wśród twórców współczesnych definicji i koncepcji jakości, oprócz Crosby'ego, warto wymienić m.in. Jurana, Deminga oraz Feigenbauma. Szereg definicji wskazuje na powiązania pojęcia ,jakość” z terminem „doskonałość”, przy czym jak podkreśla Szczepańska, jakość to raczej droga do tego, aby się zbliżyć do doskonałości [Szczepańska 2011].

Zagadnienia związane z jakością są niezwykle istotne w odniesieniu do żywności, która stanowi najważniejszą grupę artykułów konsumpcyjnych [Urban 2002]. W tym znaczeniu jakość i bezpieczeństwo żywności jest fundamentem życia społecznego i gospodarczego. Wprowadzane do obrotu artykuły rolno-spożywcze powinny spełniać określone w przepisach wymagania. Jakość produktów żywnościo- 
wych, w tym jakość handlowa, ze względu na wpływ na zdrowie, jest bardzo ważna dla konsumentów. Wraz z rozwojem rynku żywnościowego oraz ze wzrostem świadomości konsumenckiej problematyka jakości artykułów żywnościowych nabiera dodatkowego znaczenia.

Omawiając problematykę jakości handlowej artykułów rolno-spożywczych w Polsce, warto zwrócić szczególną uwagę na działalność Inspekcji Jakości Handlowej Artykułów Rolno-Spożywczych (IJHARS). Instytucja ta sprawuje nadzór nad jakością handlową artykułów rolno-spożywczych i na mocy ustawy o jakości handlowej artykułów rolno-spożywczych [Ustawa... 2000] przejęła zadania dwóch podmiotów: Centralnego Inspektoratu Standaryzacji oraz Inspekcji Skupu i Przetwórstwa Artykułów Rolnych. Celem działania Inspekcji jest przede wszystkim ochrona konsumentów i przeciwdziałanie zafałszowaniom na ryku produktów żywnościowych. IJHARS podlega pod Ministerstwo Rolnictwa i Rozwoju Wsi i odgrywa ważną rolę w realizacji polityki żywieniowej kraju. Instytucjami uprawnionymi do kontroli jakości handlowej artykułów rolno-spożywczych są również Inspekcja Handlowa oraz Urząd Ochrony Konkurencji i Konsumentów.

Głównym przedmiotem rozważań w niniejszej pracy jest jakość handlowa artykułów rolno-spożywczych. Przez pojęcie jakości handlowej, zgodnie z art. 3 ustawy o jakości handlowej artykułów rolno-spożywczych [Ustawa... 2000], rozumieć należy „cechy artykułu rolno-spożywczego dotyczące jego właściwości organoleptycznych, fizykochemicznych i mikrobiologicznych w zakresie technologii produkcji, wielkości lub masy oraz wymagania wynikające ze sposobu produkcji, opakowania, prezentacji i oznakowania, nie objęte wymaganiami sanitarnymi, weterynaryjnymi lub fitosanitarnymi". Nowelizacje ustawy, w tym m.in. Ustawa z dnia 24 października 2008 r. o zmianie ustawy o jakości handlowej artykułów rolno-spożywczych oraz niektórych innych ustaw, rozszerzyły zakres przedmiotowy nadzoru Inspekcji Jakości Handlowej Artykułów Rolno-Spożywczych, dostosowując polskie przepisy prawne do rozporządzeń Wspólnoty Europejskiej. W znowelizowanej ustawie wprowadzono także definicję artykułu rolno-spożywczego zafałszowanego, tj. produktu, „którego skład jest niezgodny z przepisami dotyczącymi jakości handlowej poszczególnych artykułów rolno-spożywczych, albo produkt, w którym zostały wprowadzone zmiany, w tym zmiany dotyczące oznakowania, mające na celu ukrycie jego rzeczywistego składu lub innych właściwości, jeżeli niezgodności te lub zmiany w istotny sposób naruszają interesy konsumentów”. Należy podkreślić, że istnieją różne możliwości i formy fałszowania żywności, m.in. poprzez dodanie substancji zmieniających skład lub obniżających wartość odżywczą lub zafałszowanie przez odjęcie składnika lub zmniejszenie zawartości jednego składnika lub kilku składników decydujących o wartości odżywczej.

Kontrole jakości handlowej artykułów rolno-spożywczych realizowane przez IJHARS stanowią istotny element systemu gwarantowania jakości żywności w Polsce.

Celem niniejszej pracy była ocena zmian jakości handlowej wybranych grup artykułów rolno-spożywczych w Polsce w latach 2010-2012. Głównym źródłem in- 
formacji były raporty z kontroli przeprowadzonych przez pracowników Inspekcji Jakości Handlowej Artykułów Rolno-Spożywczych. Do szczegółowych analiz (przykładów uchybień) wytypowano pięć grup produktów, w których wykryto wiele nieprawidłowości związanych z omawianą problematyką. Szczególną uwagę w niniejszej pracy poświęcono kwestii braku autentyczności i zafałszowań produktów żywnościowych w Polsce.

\section{IJHARS jako instytucja uprawniona do kontroli jakości handlowej - zadania i funkcjonowanie}

Inspekcja Jakości Handlowej Artykułów Rolno-Spożywczych sprawuje nadzór nad jakością handlową artykułów rolno-spożywczych poprzez kontrole jakości w produkcji i obrocie (w tym artykułów rolno-spożywczych wywożonych za granicę i sprowadzanych z zagranicy) oraz dokonywanie ocen i wydawanie świadectw w zakresie jakości handlowej. Kontrole artykułów rolno-spożywczych przeprowadzane przez IJHARS obejmują sprawdzenie:

- cech organoleptycznych (wygląd, smak, zapach, barwa);

- parametrów fizykochemicznych (na podstawie badań laboratoryjnych, np. zawartości tłuszczu, białka, skrobi, soli);

- znakowania produktów żywnościowych.

Zgodnie z art. 23 ustawy o jakości handlowej artykułów rolno-spożywczych kontrola jakości realizowana przez IJHARS ma na celu sprawdzenie, czy [Ustawa... 2000]:

- artykuły rolno-spożywcze spełniają wymagania w zakresie jakości handlowej określone w przepisach o jakości handlowej oraz dodatkowe wymagania dotyczące tych artykułów, jeżeli ich spełnienie zostało zadeklarowane przez producenta;

- artykuły rolno-spożywcze są składowane lub transportowane w sposób zapewniający zachowanie ich właściwej jakości handlowej;

- ilość i jakość składowanego artykułu rolno-spożywczego są zgodne z ustalonymi warunkami składowania.

Na rysunku 1 przedstawiono schemat organizacyjny IJHARS z podziałem na szczebel centralny i wojewódzki.

Działalnością IJHARS kieruje główny inspektor jakości handlowej artykułów rolno-spożywczych, który podlega ministrowi właściwemu do spraw rynków rolnych. Główny inspektor jest powoływany (i odwoływany) na wniosek ministra właściwego do spraw rynków rolnych przez Prezesa Rady Ministrów. Na szczeblu wojewódzkim ważnym organem IJHARS jest 16 wojewódzkich inspektoratów. Kontrole jakości handlowej artykułów rolno-spożywczych w dużej mierze prowadzone są w laboratoriach Głównego Inspektoratu Jakości Handlowej Artykułów Rolno-Spożywczych na podstawie pobranych podczas czynności kontrolnych pró- 


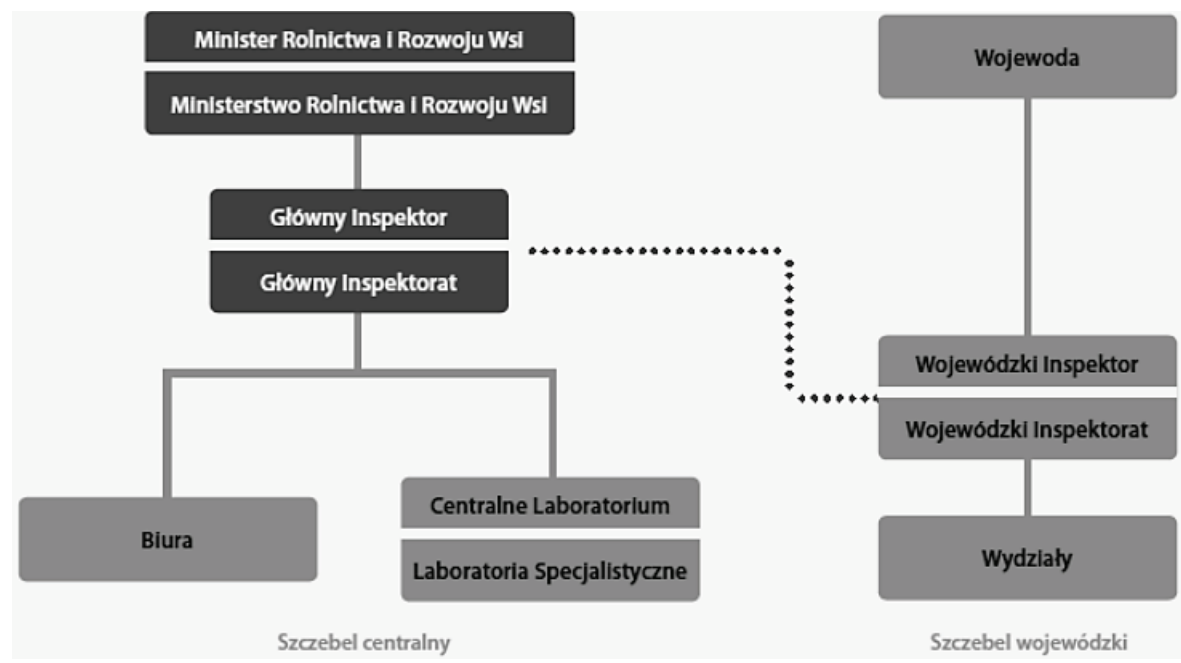

Rysunek 1. Schemat organizacyjny IJHARS

Źródło: [Sprawozdanie Roczne 2012... 2013, s. 58].

Figure 1. AFQI Organization Chart

Source: [Sprawozdanie Roczne 2012... 2013, s. 58].

bek artykułów rolno-spożywczych. Bazę laboratoryjną stanowi obecnie 7 laboratoriów, w tym Centralne Laboratorium w Poznaniu, oraz 6 laboratoriów specjalistycznych (w Białymstoku, Gdyni, Kielcach, Lublinie, Rzeszowie oraz Szczecinie). Zakres przedmiotowy przeprowadzanych w laboratoriach GIJHARS badań laboratoryjnych artykułów rolno-spożywczych obejmuje ich właściwości organoleptyczne, fizykochemiczne i mikrobiologiczne w zakresie technologii produkcji, cech fizycznych (np. wielkość, masa) oraz wymagań wynikających ze sposobu produkcji, opakowania, prezentacji i oznakowania. W laboratoriach GIJHARS stale poszerza się zakres analiz, w tym z obszaru chemii klasycznej instrumentalnej, co skutkuje poprawą jakości prac analitycznych i możliwością dokonywania specjalistycznych analiz [Sprawozdanie... 2012]. Ocena w specjalistycznych laboratoriach dokonywana jest na podstawie wyników badań fizykochemicznych, mikrobiologicznych oraz oceny sensorycznej.

\section{Wyniki kontroli jakości handlowej artykułów rolno-spożywczych przeprowadzonych przez IJHARS w latach 2010-2012}

Liczbę kontroli przeprowadzanych przez IJHARS oraz liczbę pobranych próbek zbadanych w laboratoriach GIJHARS w latach 2010-2012 przedstawiono na rys. 2 i 3. 


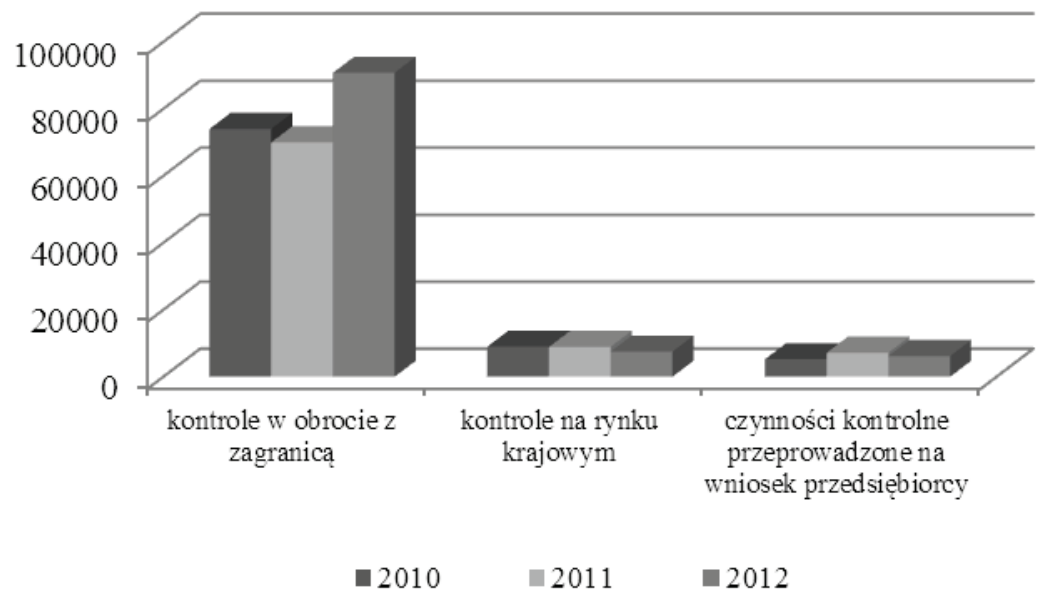

Rysunek 2. Liczba kontroli przeprowadzonych przez IJHARS

Źródło: opracowanie własne na podstawie [Sprawozdanie... 2012, s. 19; Sprawozdanie... 2013, s. 19].

Figure 2. Number of controls performed by AFQI

Source: own elaboration based on [Sprawozdanie... 2012, s. 19; Sprawozdanie... 2013, s. 19].

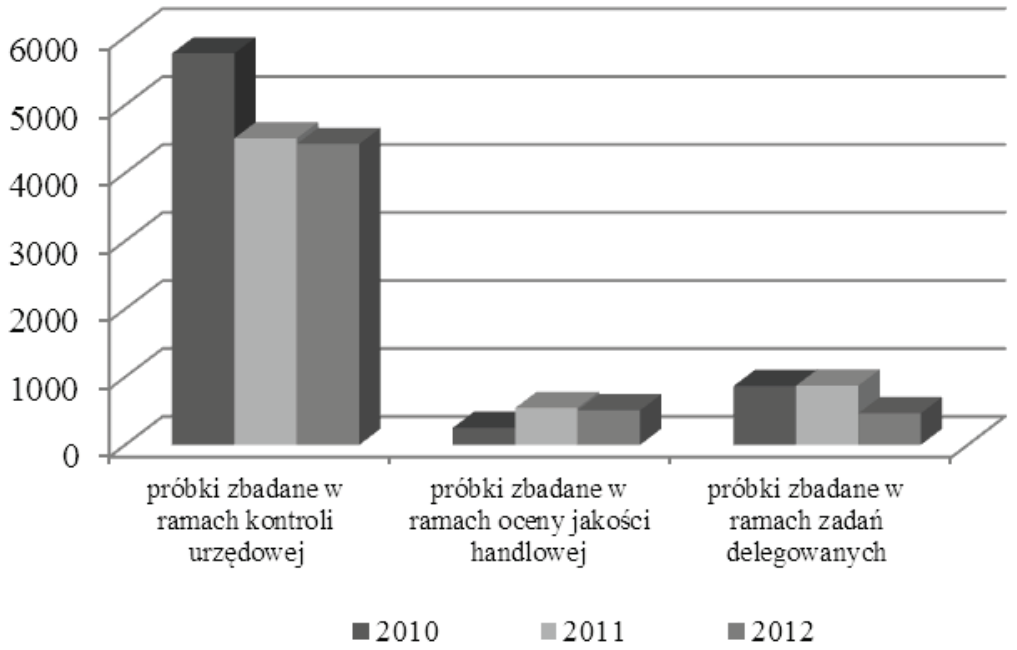

Rysunek 3. Liczba próbek artykułów rolno-spożywczych zbadanych w laboratoriach IJHARS w latach 2010-2012

Źródło: opracowanie własne na podstawie [Sprawozdanie... 2012, s. 19; Sprawozdanie... 2013, s. 19].

Figure 3. Number of the agricultural and food product samples tested in the AFQI laboratories in the years 2010-2012

Source: own elaboration based on [Sprawozdanie... 2012, s. 19; Sprawozdanie... 2013, s. 19]. 
Liczba przeprowadzonych czynności kontrolnych ogółem w latach 2010-2012 wyniosła 27 8792, z czego 84,2\% stanowiły kontrole w obrocie z zagranicą. Warto zaznaczyć znaczący wzrost liczby kontroli w obrocie z zagranicą w 2012 r. w porównaniu $\mathrm{z}$ rokiem $2011 \mathrm{r}$.

Na rysunku 3 przedstawiono zestawienie liczby próbek artykułów rolno-spożywczych zbadanych w laboratoriach GIJHARS w badanym okresie.

W ramach kontroli przeprowadzonych w latach 2010-2012 w laboratoriach IJHARS analizie poddano 18199 próbek, z czego 14695 próbek w ramach kontroli urzędowych (planowanych i doraźnych). W 2012 r. laboratoria Inspektoratu zbadały ogółem 5397 próbek artykułów rolno-spożywczych (z czego 4426 próbek w ramach kontroli urzędowej), wykonując łącznie 40435 oznaczeń parametrów jakościowych.

Nadzór nad jakością handlową artykułów rolno-spożywczych sprawowany przez Inspekcję Jakości Handlowej Artykułów Rolno-Spożywczych w latach 20102012 wykrył wiele nieprawidłowości (tab. 1).

Tabela 1. Udział próbek o niewłaściwej jakości handlowej z uwzględnieniem wybranych grup towarowych skontrolowanych w ramach planowych i doraźnych kontroli IJHARS w latach 2010-2012

Table 1. Proportion of inappropriate commercial quality samples including selected product groups controlled under scheduled and ad hoc AFQI controls in the years 2010-2012

\begin{tabular}{|l|r|r|r|}
\hline \multirow{2}{*}{ Grupa towarowa } & 2010 & 2011 & 2012 \\
\cline { 2 - 4 } & \multicolumn{3}{c|}{$[\%]$} \\
\hline Pieczywo cukiernicze, ciasta i ciastka & 9,9 & 17,1 & 33,3 \\
\hline Wyroby cukiernicze & 3,4 & 10,1 & 22,2 \\
\hline Koncentraty spożywcze & b.d. & 0 & 11,7 \\
\hline Mięso i jego przetwory & 14 & 15 & 22,4 \\
\hline Napoje spirytusowe & 20 & 0 & 5 \\
\hline Wyroby garmażeryjne & 16,8 & 11,4 & 16,2 \\
\hline Ryby i ich przetwory & 19,9 & 17,1 & 20,1 \\
\hline Piwo i surowce browarnicze & 22,7 & 13 & 15,3 \\
\hline Drób i jego przetwory & 3,7 & 11 & 12,9 \\
\hline Przetwory owocowo-warzywne & b.d. & 153 & 16,6 \\
\hline Pieczywo & 7,8 & 18,6 & 16,3 \\
\hline Przyprawy & b.d. & 9,8 & 6,6 \\
\hline Wyroby winiarskie & 6,3 & 7,5 & 4,2 \\
\hline Oliwa z oliwek & 4,7 & 6,3 & 0 \\
\hline Przetwory mleczne & 17,8 & 22,8 & 16,2 \\
\hline Miód & 28,3 & 50 & 31,1 \\
\hline
\end{tabular}

Źródło: opracowanie własne na podstawie [Sprawozdanie...2012, s. 20; Sprawozdanie... 2013, s. 20]. Source: own elaboration based on [Sprawozdanie...2012, s. 20; Sprawozdanie... 2013, s. 20 ]. 
W latach 2010-2012 udział próbek artykułów rolno-spożywczych o niewłaściwej jakości handlowej ogółem wzrósł o 1 punkt procentowy (tj. z 16,2\% do 17,2\%). $\mathrm{W}$ ramach wymienionych $\mathrm{w}$ tab. 1 grup towarowych odnotowano wzrost udziału próbek o jakości handlowej niezgodnej z wymaganiami lub deklaracją producenta głównie w przypadku grup:

- pieczywo cukiernicze, ciasta i ciastka (wzrost o 23,4 punktu procentowego),

- wyroby cukiernicze (wzrost o 18,8 punktu procentowego),

- drób i jego przetwory (wzrost o 9,2 punktu procentowego),

- pieczywo (wzrost o 8,5 punktu procentowego),

- mięso i jego przetwory (wzrost o 8,4 punktu procentowego).

W kilku kategoriach produktów w badanych latach odnotowano zmniejszoną liczbę udziału próbek o niewłaściwej jakości handlowej, tj. w przypadku napojów spirytusowych oraz piwa i surowców browarniczych.

Jak wspomniano wcześniej, pieczywo cukiernicze, ciasta i ciastka; wyroby cukiernicze oraz pieczywo to grupy artykułów rolno-spożywczych, w których w badanych latach IJHARS wykryła wiele nieprawidłowości. Stwierdzone niezgodności dotyczyły m.in. nazw handlowych oraz masy i składu produktów. Uchybienia odnośnie do nazw wiązały się ze stosowaniem nazw lub z podawaniem błędnych informacji sugerujących inny rodzaj produktów. Jak wskazują Diakun i Wieliczko [2013], ustawodawstwo w zakresie znakowania i jakości handlowej pieczywa nakłada obowiązek na producenta tworzenia nazw handlowych adekwatnych do deklarowanego składu (np. pieczywo żytnie, jeśli zostało wyprodukowane faktycznie z mąki żytniej). Na przykład w 2010 r. podczas kontroli IJHARS nieprawidłowości dotyczyły m.in. bezpodstawnego użycia przez producentów pieczywa określeń: „,bez konserwantów”, „tradycyjne polskie pieczywo”, „najlepsze pieczywo”, „wyłącznie z naturalnych składników”, „tradycja smaku”, „non gmo" - sugerujących specjalne właściwości produktu, bez ich potwierdzenia w dokumentacji zakładowej [Sprawozdanie... 2011]. Wykrycie nieprawidłowości w oznakowaniu produktów oraz zafałszowania produktów jest istotne z punktu widzenia konsumentów, gdyż błędne oznakowanie produktu lub zafałszowanie składu mogą spowodować niebezpieczeństwo zaburzeń zdrowotnych (np. u osób z nietolerancją pewnych składników pokarmowych). Nieprawidłowości wykazane w ramach kontroli IJHARS dotyczyły także masy pieczywa, w tym stwierdzono niedobory masy jednostkowej produktów. Uchybienia dotyczące parametrów fizykochemicznych dotyczyły m.in. zawyżonej zawartości tłuszczu w przeliczeniu na suchą masę oraz zaniżonej zawartości cukrów ogółem w suchej masie.

Nieprawidłowości w grupie towarowej „drób i jego przetwory”, wykryte podczas kontroli IJHARS w latach 2010-2012, dotyczyły zarówno cech organoleptycznych, jak i parametrów fizykochemicznych. Można wyszczególnić kilka głównych nieprawidłowości; są nimi:

- $\quad$ wygląd (np. pozostałości piór, krwiste plamy na filetach z piersi kurczaka, przebarwienia skórne na części piersiowej tuszy oraz ciemne plamy przy stawie skokowym), 
- zawyżona zawartość wody i tłuszczu,

- zaniżona zawartości białka,

- obecność niezadeklarowanych składników (m.in. fosforu, azotanów i azotynów, surowców sojowych).

Szczegółowe kontrole produktów w grupie „mięso i przetwory” wykryły nieprawidłowości parametrów fizykochemicznych oraz znakowania produktów, w tym m.in.:

- obecność niezadeklarowanych surowców przez producenta żywności (np. surowiec drobiowy w wyrobie deklarowanym jako wieprzowy) oraz innych substancji, w tym konserwujących i zwiększających wodochłonność;

- zawyżoną zawartość wody i tłuszczu oraz zaniżoną zawartość białka w stosunku do poziomów tych parametrów określonych w dokumentach normalizacyjnych,

- brak wskazania w wykazie składników wszystkich surowców użytych do produkcji (np. surowca pochodzenia zwierzęcego innego niż deklarowany, alergenów, dozwolonych substancji dodatkowych, wody, soli, aromatów czy przypraw),

- nieprecyzyjne oznaczenie wyrobu gotowego, tj. brak określenia rodzaju wyrobu (np. kiełbasa wieprzowa), stopnia rozdrobnienia surowca (np. kiełbasa homogenizowana), procesu technologicznego i sposobu obróbki termicznej zastosowanej w procesie produkcji (np. kiełbasa parzona, wędzona, suszona);

- wprowadzania konsumentów w błąd co do trwałości produktu (w tym bezpodstawne wydłużenie terminu przydatności oraz inne (np. użycie określeń: „,staropolska”, „tradycyjnie wyrabiana”, „domowa”, „wiejska” przy jednoczesnym stosowaniu fosforanów, wzmacniaczy smaku, aromatów dymu wędzarniczego itp.).

\section{Zakończenie}

Kontrola jakości handlowej artykułów rolno-spożywczych, ze względu na społeczne i gospodarcze znaczenie żywności, jest istotnym elementem gwarantowania konsumentom rzetelnych informacji na temat artykułów rolno-spożywczych. Ważną rolę w tym względzie w Polsce odgrywa Inspekcja Jakości Handlowej Artykułów Rolno-Spożywczych, której działania koncentrują się na ochronie konsumentów i walce z zafałszowaniami na rynku produktów żywnościowych. Funkcjonowanie systemu kontroli i certyfikacji jakości handlowej artykułów rolno-spożywczych w Polsce, którego ważnym ogniwem jest IJHARS, zwiększa bezpieczeństwo konsumentów żywności.

Analizy wyników kontroli przeprowadzanych przez IJHARS w latach 2010-2012 wskazały, że konsumenci w Polsce są narażeni na wiele nieprawidłowości w cechach organoleptycznych, parametrach fizykochemicznych oraz oznakowaniu żywności. Jak wynika z analiz, w badanym okresie wzrosła liczba próbek o niewła- 
ściwej jakości handlowej w grupach towarowych: „pieczywo cukiernicze, ciasta i ciastka”, „wyroby cukiernicze”, ,pieczywo”, „drób i jego przetwory” oraz „mięso i jego przetwory". Popełniane błędy wynikać mogą zarówno z niepełnej wiedzy producentów, jak i celowych, nieuczciwych praktyk. Z punktu widzenia społecznej odpowiedzialności producentów żywności niedopuszczalne jest stosowanie nazw rodzajowych nieadekwatnych do użytych surowców i zastosowanych procesów technologicznych (m.in. niewłaściwe podawanie informacji dotyczących wartości odżywczej, podmian gatunkowych mięsa, pominięcie informacji o składniku alergennym, umieszczenie na opakowaniach zdjęć surowców/składników, których nie użyto do produkcji).

Jak wynika z przedstawionych w niniejszej pracy wyników kontroli poziomu jakości handlowej żywności w Polsce, jakość wielu produktów na rynku żywnościowym nie odpowiada wymaganiom norm oraz jest niezgodna $\mathrm{z}$ deklaracjami producentów. Ze względu na to, że są to podstawowe produkty konsumpcyjne, problematyka zafałszowań wiąże się ściśle z bezpieczeństwem konsumentów. Istotny jest zwłaszcza problem ilościowego i jakościowego fałszowania składu produktów.

\section{Literatura}

Diakun J., Wieliczko W., Prawidłowości znakowania i jakość handlowa pieczywa w dystrybucji handlowej, „Inżynieria Przetwórstwa Spożywczego” 2013, nr 2/4, s. 9-13.

Kiliński A., Jakość, WNT, Warszawa 1979, s. 13.

Kołodziejczyk M., Kowrygo B., Urzędowe kontrole zafatszowań środków spożywczych w świetle obowiąującego prawa żywnościowego, „Problemy Rolnictwa Światowego” 2008, t. 5, s. 23-32.

Łuczak J., Metody i techniki zarządzania jakościa: kompendium wiedzy, Wydawnictwo Quality Progress, Poznań 2007, s. 27.

Rozporządzenie Ministra Rolnictwa i Rozwoju Wsi z dnia 25 maja 2005 r. zmieniające rozporządzenie w sprawie szczegółowych zasad organizacji Inspekcji Jakości Handlowej Artykułów Rolno-Spożywczych (Dz.U. 2005 nr 99, poz. 829).

Sprawozdanie Roczne 2010, GIJHARS, Warszawa 2011, s. 26.

Sprawozdanie Roczne 2011, GIJHARS, Warszawa 2012, s. 19-20, 59.

Sprawozdanie Roczne 2012, GIJHARS, Warszawa 2013, s. 19-20.

Szczepańska K., Zarządzanie jakością. W dążeniu do doskonałości, Wydawnictwo C. H. Beck, Warszawa 2011, s. 24.

Urban S., Marketing produktów spożywczych, Wydawnictwo AE we Wrocławiu, Wrocław 2002, s. 21

Ustawa o jakości handlowej artykułów rolno-spożywczych z dnia 21 grudnia 2000 r. (Dz. U. 2005 nr 187, poz. 1577 z późn. zm.).

Zarządzenie Ministra Rolnictwa i Rozwoju Wsi z dnia 15 lipca 2009 r. (Dz. Urz. Min. Rol. nr 18, poz. 62). 


\section{COMMERCIAL QUALITY OF SELECTED AGRICULTURAL AND FOOD PRODUCT GROUPS IN POLAND}

Summary: The article presents selected issues on commercial quality of selected groups of agri-food products in Poland in 2010-2012. As evident from the analyses performed, the studied period featured an increase in the quantity of samples with inadequate commercial quality, e.g. in the product group of pastry, cakes; confectionery, bakery products; poultry and its products, as well as meat and meat products. A comparison of the control results indicated an increase of commercial quality of spirit drinks, beer and brewing materials. The article presents examples of misconduct related to the compliance with the rules of commercial quality of selected agricultural and food product.

Keywords: commercial quality, food, Agricultural and Food Quality Inspection (AFQI). 